DOI: $\square$ https://doi.org/10.15407/techned2020.04.060

\title{
MANAGEMENT OF MODES OF DISTRIBUTIVE ELECTRIC NETWORKS OF CITIES UNDER CONDITIONS OF WEAK CORRELATION OF GRAPHICS OF ACTIVE AND REACTIVE POWER
}

Journal

Publisher

ISSN

Issue

Pages
Tekhnichna elektrodynamika

Institute of Electrodynamics National Academy of Science of Ukraine 1607-7970 (print), 2218-1903 (online)

No 4, 2020 (July/August)

$60-66$

\section{Authors}

P.P. Govorov ${ }^{1}$, V.O. Novskiy ${ }^{2}$, V.P. Govorov ${ }^{1}$, A.K. Kindinova ${ }^{1}$

1- O.M. Beketov Kharkiv National University of Urban Economy,

Marshala Bazhanova str., 17, Kharkiv, 61000,Ukraine,

e-mail: philip.govorov@gmail.com

2- Institute of Electrodynamics National Academy of Science of Ukraine,

Peremohy ave., 56, Kyiv, 03057, Ukraine,

e-mail: novsky@ied.org.ua

* ORCID ID : https://orcid.org/0000-0002-0379-1448

** ORCID ID : https://orcid.org/0000-0003-3857-7027

\begin{abstract}
Settlement and experimental studies of the use of filter-compensating devices for use in lighting electrical networks and phase-switched booster transformers for controlling the flows of active and reactive powers are presented. The analysis of component capacities in the conditions of non-linearity of the characteristics of their consumers and low correlation of voltage and reactive power in urban distribution networks is carried out. References 9 , figures 5.
\end{abstract}

Key words: phase-switched booster transformers, filter-compensating devices, reactive power, urban distribution networks, control, mode. 
Received: 28.02.2020

Accepted: 08.04.2020

Published: 26.06.2020

\section{References}

1. Hovorov F.P., Hovorov V.F., Teroshyn O.V., Chetverykova Y.M. A comprehensive solution to voltage regulation and reactive power compensation in lighting electrical networks. Tekhnichna elektrodynamika

. Tematycnyi vypusk "Sylova elektronika ta energoefektyvnist". 2009. No1. Pp. 47-50. (Rus).

2. Kroherys A.F., Rashevyts K.K., Treimanys E P., Shynka Ya.K. AC power. Ryha:

Fyziko-energeticheskii institute Latviiskoi akademii nauk, 1993. 294 p. (Rus).

3. Artemenko M.lu., Batrak L.M., Polishchuk S.I. Active current and apparent power of three-phase power systems. Tekhnichna elektrodynamika. 2018. No 6. Pp. 69-72. (Ukr). DOI: https://doi.org/10.15407/techned2018.06.069

4. Govorov P.P., Govorov V.P., Korol O.V. Reactive power compensation in electrical circuits whit discharge lamps. Proceeding International Scientific Conference (UNITECH-14). Gabrovo, 21-22 November, 2014. Vol. 1. Pp. 59-65.

5. Shydlovskyi A.K., Novskyi V.O., Zharkin A.F. Stabilization of electrical parameters in three-phase systems by semiconductor corrective devices. Kyiv: Nash format, 2013. 378 p. (Ukr).

6. Lypkivskyi K.O., Mozharovskyi A.H. Features of realization of function of transformation of the transformer-key executive structure of the regulator-stabilizer of alternating current. Tekhnic hna elektrodynamika

. 2017. No 2. Pp. 35-39. (Ukr). DOI:

https://doi.org/10.15407/techned2017.02.035

7. Tirshu M., Kalinin L., Zaitsev D., Golub I., Spivak V., The model and characteristics of circular phase convertor. 10th International Conference and Exhibition on Electromechanical and Power Systems octombrie. 2015. Pp.180-184.

8. Kalinin L., Zaitsev D., Tirshu M., Golub I. Modeling a cyclo-converter based on a phase shifter with circular conversion. IV International Conference Intelligent Energy Systems ESS'15. Kyiv, 9-12 June, 2015. Pp. 317-321. (Rus).

9. Kalinin L., Zaitsev D., Tirshu M., Golub I. Capabilities for improving the control strategy of direct frequency conversion by using the phase-shifting transformer with power electronic switching equipment. International conference Energy of Moldova - 2016. Regional aspects of development

October, 2016. Pp.214-221.

. Chisinau, Republic of Moldova, 29 September - 01 
$\underline{\text { PDF }}$

@ $\Theta \Theta \odot$

This work is licensed under a Creative Commons Attribution-NonCommercial-NoDerivatives 4.0 International License 